The research program of the Center for Economic Studies (CES) produces a wide range of theoretical and empirical economic analyses that serve to improve the statistical programs of the U.S. Bureau of the Census. Many of these analyses take the form of CES research papers. The papers are intended to make the results of CES research available to economists and other interested parties in order to encourage discussion and obtain suggestions for revision before publication. The papers are unofficial and have not undergone the review accorded official Census Bureau publications. The opinions and conclusions expressed in the papers are those of the authors and do not necessarily represent those of the U.S. Bureau of the Census. Republication in whole or part must be cleared with the authors.

\title{
ANALYSIS OF YOUNG NEIGHBORHOOD FIRMS SERVING URBAN MINORITY CLIENTS
}

\author{
by
}

Timothy Bates *

Wayne State University

and

\author{
Alicia Robb * \\ University of California, Santa Cruz
}

CES 08-11 May, 2008

\begin{abstract}
All papers are screened to ensure that they do not disclose confidential information. Persons who wish to obtain a copy of the paper, submit comments about the paper, or obtain general information about the series should contact sang V. Nguyen, Editor, Discussion Papers, Center for Economic Studies, Bureau of the Census, 4600 Silver Hill Road, 2K132F, Washington, DC 20233, (301-763-1882) or INTERNET address sang.v.nquyen@census.gov.
\end{abstract}




\begin{abstract}
This study empirically investigates Michael Porter’s hypothesis that urban minority neighborhoods offer attractive opportunities to household-oriented businesses, such as retail firms (1995). Our analysis compares the traits and performance of firms serving predominantly minority clients to those selling their products largely to clients who are nonminority whites. Controlling statistically for applicable firm and owner characteristics, our findings indicate that the minority neighborhood niche does not offer young firms an attractive set of opportunities. Relative to opportunities in the corresponding nonminority household niche and the broader regional marketplace, the neighborhood minority household market is associated with reduced business viability.
\end{abstract}

Keywords: Entrepreneurship, Business Performance, Inner City Markets

* The authors would like to thank Mark Doms for helpful comments. The research in this paper was conducted while one of the authors was a Special Sworn Status researcher of the U.S. Census Bureau at the Center for Economic Studies. Research results and conclusions expressed are those of the authors and do not necessarily reflect the views of the Census Bureau. This paper has been screened to insure that no confidential data are revealed. The data can be obtained at a Census Research Data Center or at the Center for Economic Studies (CES) only after approval by the CES and IRS. See http://www.ces.census.gov/ for details on the application and approval process. 


\section{Introduction}

Urban minority communities are typically portrayed as declining areas plagued by a loss of economic base, disinvestment in housing stock, and low rates of business formation (Fusfeld, 1973; Schaffer, 1973; Bates, 1993). Because residents of these communities often have low and variable personal incomes, low rates of labor force participation, and high unemployment rates, minority communities tend to have weak internal markets. This weakness, in turn, attenuates the local business community serving those markets (see, for example, Caplovitz, 1967; Fusfeld and Bates, 1984).

Michael Porter launched a new trajectory in urban research, taking the position that disinvestment had gone too far: inner-city, predominantly minority communities by the 1990s had become promising sites for business creation and expansion (1995). Despite their low average incomes, "the consumer market of inner-city residents represents the most immediate opportunity for inner-city-based entrepreneurs...” (Porter, 1997, p. 14). These opportunities had been overlooked in part, because of the "many misperceptions and biases about inner cities and their opportunities - what economists call information imperfections” (Porter, 1997, p.17).

Inner-city markets are poorly served, according to Porter, resulting in unmet local demand, particularly in retailing and consumer services (1995). Despite low average resident incomes, high population density translates into “an immense market with substantial purchasing power” (p. 58). Making this opportunity even more attractive to potential business entrants is the fact that "there tend to be few competitors serving it" (Porter, 1997, p. 14). 
An alternative interpretation of the generally distressed economic state of urban minority communities is the notion that the "market" is working: profit-seeking firms are correctly gauging opportunities and choosing rationally to invest elsewhere. Doeringer makes this point, observing "it is hard to think of changes in market institutions that might improve the efficiency of inner-city businesses sufficiently to promote growth... From the perspective of inner-city economic development, the problem would seem to be less one of market failures than of well-functioning markets...” (1999, p. 512).

The conventional wisdom on the attractiveness of investing in inner-city minority communities evolved in a time period (1960s to 1980s) of rapid net out migration of population and large-scale disinvestments by established enterprises. These same areas often stabilized in the 1990s (Hill and Brennan, 2005). Substantial progress -- population stabilization, even slight poverty reduction -- was apparent between 1990 and 2000 in many census tracts where concentrated poverty had been pronounced in 2000 (Berube and Frey, 2005). The fact that these areas might have been poor prospects for small business creation in the 1970s and early 1980s (Bates, 1989) does not logically indicate that similarly weak prosects awaited new firms venturing into these same areas in the 1990s. The very disinvestment process documented by scholars like Schaeffer (1973) may have reduced the capacity of local businesses to the point where the previously harsh small-business operating environment was erased. The logic of Porter's underserved market position indeed suggests that the earlier period of disinvestment was overdone.

Several studies have empirically addressed the Porter hypothesis. Alwitt and Donley (1997) analyzed numbers and types of retail establishments in 53 Chicago neighborhoods, using individual zip codes as their “neighborhood” proxy. Comparing 
the retail presence in Chicago's poorest zip codes to the rest of the city, they calculated the number of retail outlets per million dollars in household purchasing power. They found a city-wide ratio of .413 retail outlets per million dollars in purchasing power, with retail presence thusly measured not differing significantly in the poor zip code areas versus the rest of the city. Some differences did emerge, such as poor areas that had a greater density of liquor stores per dollar of purchasing power than did wealthier areas. Yet no evidence that poor inner-city neighborhoods with "enormous buying power are going unserved” (ICIC and the Boston Consulting Group, 1998) was forthcoming.

Porter's underserved market hypothesis has been indirectly addressed by scholars tracking the large-scale expansion of Korean immigrant-owned firms in urban African American neighborhoods. Yoon (1997), for example, claimed that absence of competition attracted Korean merchants to black communities in Chicago: they were simply "filling a vacuum..." (p. 34).

The case for expecting a riskier operating environment for small businesses serving consumer markets in inner-city neighborhoods logically rests on the same basis as Porter's hypothesis: information asymmetries, misperceptions, and the like. These certainly do exist. Constrained credit availability -- even redlining -- does appear to afflict many urban minority communities (Immergluck, 2004). Relatively higher levels of financial market development tend to produce higher levels of economic performance (and vice versa) in impacted areas (Guiso, Sapienza, and Zingales, 2004). We expect that constrained credit availability indeed reduces small-business viability in inner-city minority communities, other factors constant. A high degree of information asymmetry 
appears to typify these areas, causing credit rationing and constituting failure of the credit market to function efficiently (Craig, Jackson, and Thompson, forthcoming). ${ }^{1}$

This study empirically investigates Michael Porter’s hypothesis that urban minority neighborhoods offer attractive opportunities to household-oriented businesses, such as retail firms (1995). Our analysis compares the traits and performance of firms serving predominantly minority clients to those selling their products largely to clients who are nonminority whites. Controlling statistically for applicable firm and owner characteristics, we investigate whether or not the minority neighborhood niche offers young firms an attractive set of opportunities.

\section{Analysis of Survival Patterns among Young Firms Operating in Urban Areas}

To investigate the Porter Hypothesis, we utilize data from the Characteristics of Business Owners (CBO) Survey. ${ }^{2}$ The nearly 6,000 young firms examined below were in operation in 1992 and all relied upon households (as opposed to business and government) as a major source of sales revenues. ${ }^{3}$ Our analysis includes only those firms located within metropolitan areas that were formed in the 1986-1992 period. Our primary measure of young firm viability is survival over the 1992-1996 period- those still operating in late 1996 are the survivors; those closing down, discontinuing operations are viewed as less viable. To delineate those active in 1996 from those that discontinued during the 1992-1996 period, we utilize firm and owner traits as explanatory variables. Robustness of our firm survival analysis is investigated utilizing an alternative measure - profitability -- of firm viability. 
A growing body of literature predicts increased survival odds for well capitalized firms that are run by owners having the human capital (expertise, experience) appropriate for operating a viable venture. Owner human capital is described in the CBO data by multiple qualitative and quantitative measures of education and experience. Two types of work experience strongly predict improved firm survival prospects. First, prior work experience in a business whose products were similar to those provided by the owner's current venture is important (Bruderl, et al., 1992; Fairlie and Robb, 2007a). Second, prior experience working in a family-owned business increases the likelihood of young firm success and survival (Fairlie and Robb, 2007b). Furthermore, previous findings indicate that highly educated owners are more likely than poorly educated ones to operate firms that remain active (Bates, 1990). Quantity of owner effort, furthermore, shapes business outcomes: part-time businesses exhibit higher discontinuance rates than fulltime operations (Bates, 1997a).

The dynamics of small firm survival depend upon a variety of factors beyond owner human capital, hours of work, and financial investment in the firm. Very young firms are much more volatile and failure-prone than ventures that have built up customer goodwill and an established client base (Jovanovic, 1982; Bates, 1990). A possible shortcut to successful firm creation entails entering business by purchasing an ongoing firm that already has an established customer base.

All of these explanations are hypotheses used in this study to explain closure patterns among young household-oriented firms doing business in metropolitan America. Once these firm and owner traits are controlled for statistically, owner demographic traits - race and gender -- are expected to have little impact upon firm closure patterns. We 
undertake our analysis of isolating possible impacts of a firm's strategic choice of target market by first controlling for impacts of the applicable characteristics discussed above.

Table 1 summarizes the traits of three groups of young urban firms that were actively selling their products to urban clients in 1992. Statistics describing the entire sample of young urban household-oriented firms (column one) are presented to provide a reference point, a basis for comparison for the subgroups of interest - 1) firms serving minority clients that are located in minority neighborhoods (column two) and 2) firms in nonminority neighborhoods that are serving nonminority clients (column three). Differences in outcomes are striking: 29.0 percent of the former and 21.2 percent of the latter had shut down business operations by late 1996. Firms in minority neighborhoods serving minority clients were 36.7 percent more likely to discontinue operations, relative to firms in nonminority neighborhoods catering to a nonminority client base [(29.0 21.2)/21.2 = 36.7\%] (Table 1).

Perhaps underlying their greater tendency to close down, the minorityneighborhood-oriented ventures, were much smaller on average in terms of sales revenues, and began operations with less owner investment of financial capital than their nonminority-oriented counterparts. Annual sales averaged $\$ 76,276$ for the former and $\$ 124,199$ for the latter, while corresponding amounts of startup capital were \$30,302 and $\$ 45,259$, respectively (Table 1 ). ${ }^{4}$ Even more striking was the pattern of owner demographics across these market segments: 57.6 percent of the minority-neighborhood subgroup of firms were owned by minorities, while 85.9 percent of the firm owners in the nonminority neighborhoods were white (Table 1). In terms of the demographics of urban 
firms serving household clients, the predominant pattern is minority firms in minority neighborhoods and nonminority-owned firms in nonminority communities.

Summary statistics alone do not demonstrate that the minority-communityoriented firms are more prone to go out of business because of their decision to target a minority household clientele. Relative to their nonminority-oriented counterparts, they are younger and less capitalized businesses and their owners are less likely to possess the kinds of operational experience that are associated with heightened survival prospects (table one). To isolate possible negative consequences of targeting a minority clientele, we proceed by controlling econometrically for differences in firm and owner traits. This is undertaken in a logistic regression exercise: firms active in late 1996 are assigned a dependent variable value of one; discontinued firms are zeros. ${ }^{5}$ Results are presented in Table 2.

Our CBO sample of 4,980 small firms includes all firms that meet the selection criteria of being young, urban, active in 1992, and household oriented regarding targeted clients. The underlying CBO data (and regression results) are weighted to be nationally representative of small firms meeting these selection criteria. By late 1996, 23.2 percent of these urban businesses had discontinued and closed down.

Geographic scope of market served by the individual CBO small businesses has been defined and segmented by the "neighborhood market” explanatory variable, subdividing firms into 1) those catering to a specific neighborhood market, versus 2) those serving city-, county-, region-, or nation-wide clients. This variable was defined using owner responses to the $\mathrm{CBO}$ survey instrument (see the detailed variable definitions in the attached appendix: The CBO Data). Similarly, the "minority market" 
variable separates the firms into subgroups of those selling to household clients who are either 1) predominantly minority or 2) predominantly nonminority. These two binary variables were then interacted to create the "minority neighborhood" explanatory variable.

Findings from the logistic regression exercise, include a highly negative (-.692), statistically significant minority neighborhood variable coefficient, unambiguously indicating that targeting this niche is strongly linked to heightened firm closure prospects, other things equal. This finding stands in contradiction to Porter's hypothesis of attractive opportunities rooted in underserved markets.

Heightened likelihood of closure is not positively associated with a neighborhood orientation per se; indeed, the neighborhood-market coefficient was positive and statistically significant. Firm closure, furthermore, was not associated with the minoritymarket coefficient (which was small and insignificant statistically). It was only the interaction of these two factors (minority and neighborhood) that powerfully predicted firm discontinuance of business operations. This finding, coupled with the insignificance of the minority-market trait per se, causes us to reject the hypothesis that targeting household clients in underserved inner-city minority communities offers firms an attractive and viable avenue for success. Logistic regression findings indicate that firm survival chances are not enhanced by pursuing this strategy.

The other factors in this model largely mirror those highlighted by previous studies of small-business discontinuance patterns (Table 2). The education of the owner, prior experience in a similar line of business, experience working in a family member's business are all associated firms likely to be active at the end of 1996. The very youngest 
firms, the poorly capitalized ventures, the smaller firms lacking paid employees, in contrast, are the ones most prone to discontinue operations.

Previous research indicates that the level of startup capital is a strong predictor of business success (see for example Bates 1997 and Fairlie and Robb 2007b). Disparities in startup capital may reflect differences in the perceived potential success of firms, and thus ability to raise capital by firms. In other words, firms serving a predominantly minority clientele may have difficulty raising capital because their businesses are predicted to be less likely to succeed. If so, banks and other investors will rationally decline to invest in these businesses. Of course, an alternative explanation is that these business owners, mostly minority owners, invest less startup capital in their businesses because they have less access to capital. This may be due to having lower levels of personal and family wealth to borrow against or use as equity financing and may also be due to lending discrimination. See Robb and Fairlie (Forthcoming) for an extensive discussion on this topic. It is possible that businesses that locate in inner city neighborhoods and sell predominately to minority households could have lower survival rates because they have less outside capital on average to see them through difficult times. As Porter noted in his 1995 article (pp. 64-65), “Inner city entrepreneurs often lack personal or family savings and networks of individuals to draw on for capital.” Minority owners, although strongly attached to the neighborhood minority-market niche, were neither more nor less likely to experience firm closure than nonminority owners, controlling for firm and owner traits. The firms of immigrant owners, in contrast, were more likely to remain in operation, other things equal. Two unexpected outcomes from Table 2's logit exercise were 1) the positive association of serving neighborhood 
markets with increased firm survival prospects, and 2) the irrelevance of the owner's hours worked for predicting firm survival patterns. The geographic scope-of-market variable (neighborhood) has not, to our knowledge, been utilized previously as an explanatory factor in econometric analyses of small business viability.

Several tests of robustness of our Table 2 logistic regression analysis findings reinforce our rejection of Porter's underserved market hypothesis. First, we dropped neighborhood-oriented firms and re-estimated table two's logit exercise solely for firms serving broader city, regional, or national markets (the household clientele prerequisite was retained). We found that 10.7 percent of the firms serving these broader geographically defined markets reported that their clients were predominantly minorities. The minority orientation, once again, was found, in the logit model context, to be a small, statistically insignificant factor having no explanatory power for delineating firms still active in late 1996 from the closures.

Finally, we compared the profitability of the minority-clientele-oriented neighborhood firms to their nonminority counterparts (as defined in Table 1, Columns 2 and 3). Our measure - taxable income as reported on one’s 1992 federal income-tax return - was crude conceptually and was recorded in the CBO data only in broad interval form (zero to $\$ 10,000$, for example). Further, item nonresponse was high, reflecting the common aversion of small business owners to report profits on survey questionnaire forms. Abstracting from these issues, an underlying pattern of lower profitability typified the firms serving the minority-neighborhood market niche. Greater viability - whether measured by closure or profit differentials - characterized the small businesses operating in the nonminority neighborhood markets. 


\section{Conclusion}

We analyzed survival patterns of young urban firms, paying particular attention to the longevity of those choosing to target local household clients in minority communities. Our analysis of very large, representative samples of firms active in 1992 revealed that neighborhood businesses catering to a neighborhood minority clientele were more than 36 percent more likely than their counterparts selling predominantly to nonminority clients to close down and discontinue operations by yearend 1996. Controlling statistically for firm and owner traits - owner human capital and demographics, firm capitalization and other characteristics - the minority neighborhood niche was shown to be strongly related to small business closure and discontinuance of operations.

Our empirical findings do not support Michael Porter’s claim that urban minority neighborhoods offer attractive opportunities to household-oriented businesses, such as retail and consumer-service firms. Our further analysis of metro-area firms serving household regional and national clienteles revealed that slightly over ten percent of them derived most of their sales revenues from minority clients. Yet these businesses - which might or might not have been located in minority neighborhoods - did neither better nor worse than firms that sold predominantly to nonminority clients. Whether neighborhood or citywide in orientation regarding geographic scope of their targeted market, new and recently formed urban businesses derived no advantage, regarding survival or longevity, from serving a clientele consisting of urban minority customers predominantly.

Our findings certainly do not rule out the possibility that some type of large-scale firm, such as a Wal-Mart venture, might find a receptive environment in an inner-city 
minority community. Nor do we claim that individual small-firm ventures are doomed to marginality if they choose to do business in urban minority neighborhoods. We have not examined survival patterns of small firms that serve client segments - other business customers, government clients, and the like - outside of the household market sector. Our analysis has simply shown that the likelihood of surviving the rigors of the early stages of business operation are lower in the minority neighborhood niche, relative to other market segments in urban America. The presumed advantages that are implied in Michael Porter's underserved market hypothesis motivated us to undertake our analysis of smallfirm survival patterns. We did so by narrowly focusing upon the small-firm subset that would potentially gain most if the inner-city minority household niche did offer rich opportunities to retail and consumer-service firms in the form of abundant purchasing power and little competition. On balance, the evidence considered here does not support Porter's hypothesis of underserved markets. 


\section{Endnotes}

${ }^{1}$ For a thorough discussion of imperfect information and credit rationing, see Stiglitz and Weiss, 1981.

${ }^{2}$ See Fairlie and Robb 2007a for a detailed summary of these data.

${ }^{3}$ Well over half of all urban firms did not identify households as a major client group in their survey responses; most of these reported that their targeted market consisted of selling products to other private firms: all such firms were dropped. The data were further constrained to include only those firms with owners actively involved in running the business in 1992. To weed out "casual" businesses, we excluded those reporting sales revenues under $\$ 5,000$ in 1992, a step that reduced the sample size dramatically.

${ }^{4}$ However, given the large variances associated with annual sales, the difference between these groups is not statistically significant for this variable.

5 These data are only available through 1996, so we are not able to delineate between firms closing after 1996 with those that did not. So while we measure firm survival through 1996, we do have the issue of censoring beyond that time for the $76.8 \%$ of firms that remained active at the end of the observation period. However, our dependent variable is survival through 1996, not firm survival in general. 
Table 1: Firm and Owner Traits: Young Urban Firms

(Includes firms selling products to households)

\section{A. Owner Characteristics}

\begin{tabular}{|c|c|c|}
\hline \multirow{2}{*}{$\begin{array}{l}\text { All } \\
\text { Urban }\end{array}$} & \multicolumn{2}{|c|}{$\begin{array}{l}\text { Urban Firms Serving } \\
\text { Neighborhood Clientele }^{1}\end{array}$} \\
\hline & & Nonminority White \\
\hline Firms & Minority Clientele & Clientele \\
\hline
\end{tabular}

1. Demographic Traits

$$
\begin{aligned}
& \text { \% minority } \\
& \% \text { male } \\
& \text { \% immigrant }
\end{aligned}
$$

2. Human Capital Traits

$\%$ high school or less

$\%$ college, $1-3$ years

$\%$ college graduate

$\%$ with similar business experience

$\begin{array}{lll}14.6 \% & 57.6 \% & 15.1 \% \text { * } \\ 67.0 \% & 64.2 \% & 64.3 \% \\ 14.1 \% & 42.3 \% & 17.4 \% \text { * }\end{array}$

$\%$ with experience working in a family firm

Hours worked in the firm in 1992 (mean)

\section{B. Firm Characteristics}

Total sales revenues in 1992 (mean)

\% discontinued operations by late 1996

\begin{tabular}{ccc}
$\$ 117,681$ & $\$ 76,276$ & \multicolumn{1}{c}{$\$ 124,199$} \\
$23.2 \%$ & $29.0 \%$ & $21.2 \% *$ \\
$\$ 28,922$ & $\$ 30,302$ & $\$ 45,259 *$ \\
$25.5 \%$ & $23.8 \%$ & $33.0 \% *$ \\
$49.7 \%$ & $66.1 \%$ & $52.3 \% *$ \\
$23.5 \%$ & $100.0 \%$ & $100.0 \%$ \\
$13.9 \%$ & $100.0 \%$ & $0.0 \% *$ \\
& & \\
5838 & 593 & 1017
\end{tabular}

Number of firms

$29.1 \%$

$32.6 \%$

$37.3 \%$

$36.1 \%$

$38.4 \%$

$25.1 \%$

$37.6 \%$

$33.7 \%$ *

$54.5 \%$

$42.3 \%$

$30.1 \%$ *

$19.0 \%$

$14.0 \%$

$52.1 \%$ *

1,868

1,732

$20.2 \%$ *

1,735

Start up capitalization (mean)

$\%$ with paid employees

$\%$ started in 1991, 1992

$\%$ serving neighborhood market

$\%$ serving predominantly minority clientele

5838

593

1017

${ }^{1}$ Column 2 refers to firms that are serving a neighborhood clientele (not a broader market), which is 50 percent or more minority. Column 3 refers to firms that are serving a neighborhood clientele (not a broader market), which is less than 50 percent minority.

* Difference-in-mean tests yield statistically significant differences at the $99 \%$ level between firms serving minority versus nonminority clientele for these variables. 
Table 2: Logistic Regression Analysis: Firm Survival

Among Firms Operating in 1992, Delineating Firms Active at the End of 1996 from Closures (Includes young urban firms selling products to households only)

\begin{tabular}{|c|c|c|c|c|}
\hline & $\begin{array}{l}\text { Marginal } \\
\text { Effects }^{1}\end{array}$ & $\begin{array}{r}\text { Logistic } \\
\text { Coefficient }\end{array}$ & $\begin{array}{l}\text { Regression } \\
\text { Standard Error }\end{array}$ & \\
\hline Constant & & -2.841 & 0.534 & ]$_{\star \star \star}$ \\
\hline \multicolumn{4}{|l|}{ Education: } & \\
\hline College : $1-3$ years & -0.021 & -0.073 & 0.082 & \\
\hline College graduate & 0.056 & 0.219 & 0.099 & ** \\
\hline Graduate school & 0.189 & 0.892 & 0.139 & $\star \star \star \star ~$ \\
\hline Prior work experience in similar business & 0.073 & 0.223 & 0.073 & *** \\
\hline Prior work experience in a family member's business & 0.068 & 0.275 & 0.094 & 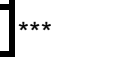 \\
\hline Owner age in years & 0.001 & 0.172 & 0.024 & 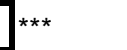 \\
\hline Owner age squared & & -0.002 & 0.00027 & *** \\
\hline Financial capital at startup (\$000) & 0.000 & 0.001 & 0.0007 & * \\
\hline Firm started de novo & -0.085 & -0.214 & 0.105 & $\star \star$ \\
\hline Year entered, 1990, 1991 or 1992 & -0.158 & -0.471 & 0.074 & 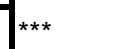 \\
\hline Owner labor input in hours (00) & 0.000 & -0.002 & 0.004 & \\
\hline Minority-owned firm & -0.001 & -0.003 & 0.132 & \\
\hline Immigrant-owned firm & 0.149 & 0.681 & 0.139 & 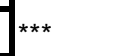 \\
\hline Female-owned firm & -0.080 & -0.27 & 0.074 & 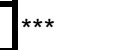 \\
\hline Employer firm & 0.188 & 0.786 & 0.109 & *夫* \\
\hline Minority market orientation & -0.053 & -0.031 & 0.142 & \\
\hline Geographic scope of market: neighborhood & 0.034 & 0.237 & 0.100 & $\star \star$ \\
\hline Minority market*neighborhood interaction & & -0.692 & 0.223 & *** \\
\hline \multirow{5}{*}{\multicolumn{5}{|c|}{$\begin{array}{lc}\text { Mean of dependent variable } & 0.7678^{2} \\
-2 \text { Log L } & 4904.6 \\
\text { Chi square } & 486.9 \\
\text { Sample size } & 4980\end{array}$}} \\
\hline & & & & \\
\hline & & & & \\
\hline & & & & \\
\hline & & & & \\
\hline \multicolumn{5}{|c|}{$\begin{array}{l}{ }^{1} \text { Marginal effects evaluated at the mean value of each regressor. For the dummy variables, the } \\
\text { marginal effects are computed as the expected change in probability from when the dummy is } 0 \text { to when } \\
\text { the dummy is } 1 \text {. For the continuous variables (age , capital, and input), the marginal probabilities are } \\
\text { computed as the change in probability when the independent variable is increased by one unit. } \\
{ }^{2} \text { Dependent variable is defined as firm survival over the period 1992-1996 (still in operation in 1996) }\end{array}$} \\
\hline
\end{tabular}




\section{Data Appendix: Variable Definitions for Table Two Logistic Regression}

Dependent variable: Active (or survive) --Firm stayed in business over the period 19921996, irrespective of presence or absence of ownership changes, then active $=1$; otherwise, active $=0$.

Female-owned firm: Firm owner is female, then female-owned firm=1; otherwise, 0.

Minority-owned firm: Firm owner is Hispanic, Black, Asian, or Native American. In multi-owner firms, the minority-owned share is $51 \%$ or higher, then minority-owned firm=1; otherwise, 0 .

Immigrant-owned firm -- Firm owner is an immigrant (not born in the US), then immigrant-owned firm=1; otherwise, 0 . (Owner can be of any race/ethnicity).

Owner age in years - self explanatory.

Owner Age squared - self explanatory.

High school (excluded variable) -- Education level of owner, has high school degree only or less, then high school $=1$; otherwise $=0$.

College, 1-3 years -- Education level of owner, has some college, then college 1-3 years $=1$; otherwise $=0$.

College graduate -- Education level of owner, has a college (bachelor's) degree, then college graduate $=1$; otherwise $=0$.

Graduate school -- Education level of owner, has some post-graduate education (masters, Ph.D., etc.), then graduate school=1; otherwise $=0$.

Prior work experience in a similar business -- Previously worked in a business similar to the one now owned, then this variable $=1$; otherwise $=0$.

Prior work experience in a family member's business -- Has worked in the past for a parent or relative who owned a business, then this variable $=1$; otherwise $=0$.

Firm started de novo -- Founded the business (compared with bought, inherited, received as a gift), then this variable $=1$; otherwise $=0$.

Owner labor input in hours -- total hours worked in a year, 1992.

Year entered, 1990, 1991, or 1992 -- Firm age is 0-2 years in 1992 (firm started 199092), then this variable $=1$; otherwise $=0$. 
Financial capital at startup - dollar amount of financial capital used at start up to launch the business.

Employer firm -- Firm has at least one employee, then employer firm $=1$; otherwise $=0$.

Minority market orientation -- Firm serves a minority market (clientele) $50 \%+$ of clients are minorities; then this variable $=1$; otherwise $=0$.

Geographic scope of market: neighborhood -- Firm serves a local market, a neighborhood clientele and not a city-wide, county-wide, regional or broader market, then this variable $=1$; otherwise $=0$.

Minority market*neighborhood interaction -- Firm serves a local market that is predominantly minority, then minority market*neighborhood interaction=1; otherwise $=0$. 


\section{$\underline{\text { References }}$}

Alwitt, Linda, and Thomas Donley. (1997.) Retail Stores in Poor Urban Neighborhoods. The Journal of Consumer Affairs 31 (1).

Bates, Timothy. (1989.) Small Business Viability in the Urban Ghetto. Journal of Regional Science 29 (4).

Bates, Timothy. (1990.) Entrepreneur Human Capital Inputs and Small Business Longevity. The Review of Economics and Statistics 72 (4).

Bates, Timothy. (1993.), Banking on Black Enterprise. Washington, D.C.: Joint Center for Political and Economic Studies.

Bates, Timothy. (1997a.) Race, Self-Employment and Upward Mobility. Baltimore: Johns Hopkins University Press.

Bates, Timothy. (1997b.) Michael Porter’s Conservative Urban Agenda Will Not Revitalize America's Inner Cities: What Will? Economic Development Quarterly 11 (1).

Bates, Timothy. (2006.) The Urban Development Potential of Black-Owned Businesses. Journal of the American Planning Association 72 (2).

Berube, A., and Frey, D. (2005.) A Decade of Mixed Blessings: Urban and Suburban Poverty in Census 2000. In Redefining Urban and Suburban America: Volume II (A. Berube, B. Katz, and R. Lang, eds.). Washington, D.C.: The Brookings Institution.

Blakely, Edward, and Small (1997.) In The Inner City (Thomas Boston and Catherine Ross, eds.). New Brunswick: Transaction Publishers.

Borjas, George, and Stephen Bronars (1989.) Consumer Discrimination and SelfEmployment. Journal of Political Economy 97 (3).

Bruderl, Josef, Peter Preisendorfer, and Rolf Ziegler. (1992.) Survival Chances of Newly Founded Organizations. American Sociological Review 57 (2).

Caplovitz, David. (1967.) The Poor Pay More. New York: The Free Press.

Craig, Ben, Jackson, William, and James Thomson (Forthcoming.) Small Firm Credit Market Discrimination, SBA Guaranteed Lending, and Local Market Economic Performance. Annals of the American Academy of Political and Social Social Science. 
Doeringer, Peter. (1999.), “Comment on Ross and Thompson,” in Ronald Ferguson and William Dickens (eds.), Urban Problems and Community Development. Washington, D.C.: Brookings Institute Press.

Fairlie, Robert and Alicia Robb (2007a.) Families, Human Capital, and Small Businesses: Evidence from the Characteristics of Business Owners Survey. Industrial and Labor Relations Review 60 (2).

Fairlie, Robert and Alicia Robb (2007b.) Why Are Black-Owned Businesses Less Successful than White-Owned Businesses: The Role of Families, Inheritances, and Business Human Capital. Journal of Labor Economics 25 (2).

Fusfeld, Daniel (1973.) The Basic Economics of the Urban Racial Crisis. New York: Holt, Rinehard, and Winston.

Fusfeld, Daniel, and Timothy Bates (1984.) Political Economy of the Urban Ghetto. Carbondale, IL: Southern Illinois University Press.

Guiso, Luigi, Sapienza, Paola, and Luigi Zingales. (2004.) Does Local Financial Development Matter? Quarterly Journal of Economics 119 (4).

Gittell, Ross and J. Phillip Thompson. (1999.) Inner City Business Development and Entrepreneurship: New Directions for Policy and Research. In Urban Problems and Community Development (Ronald Ferguson and William T. Dickens eds.). Washington, D.C.: Brookings Institute Press.

Hill, Edward, and J. Brennan. (2005.) America's Central Cities and the Location of Work: Can Cities Compete with their Suburbs? Journal of the American Planning Association 71 (4).

Immergluck, Daniel. (2004.) Credit in the Community. Armonk, N.Y.: M. E. Sharpe.

ICIC and the Boston Consulting Group. (1998.) The Business Case for Pursuing Retail Opportunities in the Inner City. Initiative for a Competitive Inner City (ICIC) working paper.

Jovanovic, Boyan. (1982.) Selection and Evolution of Industry. Econometrica 50 (2).

Light, Ivan, and Edna Bonacich. (1988.) Immigrant Entrepreneurs : Koreans in Los Angeles, 1965-1982. Berkeley: University of California Press.

Oakland, William, Fred Sparrow, and H. L. Stettler. (1971.) Ghetto Multipliers: A Case Study in Hough. Journal of Regional Science 11 (3).

Porter, Michael. (1995.) The Competitive Advantage of the Inner City. Harvard Business Review 73 (3). 
Porter, Michael. (1997). New Strategies for Inner-City Economic Development. Economic Development Quarterly 11 (1).

PriceWaterhouseCoopers. (1998.) The Inner City Shopper: A Strategic Perspective. Boston: ICIC.

Robb, Alicia, and Robert Fairlie (Forthcoming.) Access to Financial Capital among U.S. Businesses: The Case of African American Firms. The Annals of the American Academy of Political and Social Science.

Schaffer, Richard. (1973.) Income Flows in Urban Poverty Areas. Lexington, Mass.: Lexington Books.

Squires, Gregory. (2003.) Racial Profiling, Insurance Style: Insurance Redlining and the Uneven Development of Metropolitan Areas. Journal of Urban Affairs 25 (4): 347-72.

Stiglitz, Joseph, and Andrew Weiss. (1981.) Credit Rationing in Markets with Imperfect Information. American Economic Review 71 (3): 393-410.

Yoon, In-Jin (1997.) On My Own. Chicago: University of Chicago Press. 